Kees van Kersbergen og Anton Hemerijck

\title{
To årtier med forandring: Udbudspolitik og den sociale investeringsstats opståen
}

Siden sidst i 1970'erne har de europæiske lande ændret på blandingen af policies, som deres velfærdsstater var bygget op omkring. De har indført en ny politisk ortodoksi kaldet den "sociale investeringsstrategi". Med en kombination af udbudspolicies, der øger arbejdsdueligheden, og policies, der tilbyder beskyttelse, sigter strategien på at finde positivsumsløsninger på afvejningen mellem lighed og effektivitet. Artiklen sporer strategiens oprindelse og større udviklinger. I omfang svarer velfærdsreformen til et systemskifte, der går langt ud over simple nedskæringer. Skiftet er kendetegnet ved fælles trends og elementer, men der er også betydelige nationale forskelle.

Velfærdsstater er blevet tilpasset nye økonomiske og sociale krav i et helt utroligt omfang, og de har indført - godt nok med betydelig variation og under forskellige overskrifter - en ny policy-ortodoksi, som ofte kaldes "den sociale investeringsstrategi". Begrebet "social investeringsstat" blev populært gennem skriverier om "den tredje vej" i midt-1990'erne, men dens intellektuelle kilder går længere tilbage i tid. Ideen om social investering dukkede op i de tidligere 1990'ere blandt velfærdsstatsforskere og socialpolitiske konsulenter, som var bekymrede over det ensidige fokus på nedskæringer, som syntes at præge omstruktureringen af velfærdsstaten. Derfra inspirerede det socialdemokratiske og andre partiers socialpolitiske nyorientering; det blev - nogen gange modstræbende, men i det mindste i intentioner - adopteret af regeringer af forskellig overbevisning og bredte sig til internationale organisationer som OECD, FN og EU.

Et godt eksempel er det forskningsprojekt om velfærdsstater, der blev bestilt af FN's forskningsinstitut for social udvikling, UNRISD, i 1995. Projektleder og redaktør Gøsta Esping-Andersen ${ }^{1}$ brugte Skandinavien som eksempel på en velfærdsstatsreformstrategi, der bestod i at "flytte velfærdsstatsressourcer fra passiv understøttelse til fremme af beskæftigelse og familier". Helt afgørende sagde han følgende:

Scandinavia appears now to have accepted that greater inequalities are unavoidable but seeks to build in guarantees against these being concentrated in any particular stratum, or becoming permanent across people's life courses. 
In this regard, the Nordic welfare states may be said to spearhead a "social investment strategy" ... . (I)f a return to full employment will have to rely on greater earnings inequalities and a profusion of "lousy" service jobs, active social investment policies should diminish the chance that certain groups become chronic losers (1996a: 25, vores fremhævelse).

I konklusionen på UNRISD-rapporten præsenterede Esping-Andersen (1996) den sociale investeringsstrategi som en positivsumsløsning på afvejningen mellem lighed (social beskyttelse) og effektivitet (beskæftigelse) i det postindustrielle samfund. Strategien lægger vægt på at styre udbuddet af arbejdskraft og udvikle human kapital og fremmer især betingelserne for, at flere kvinder kan arbejde, uden at det går ud over børnene. Esping-Andersen slog også til lyd for en ny tilgang til lighed, som går ud over et snævert fokus på indkomstlighed "her og nu" og over til en mere dynamisk opfattelse baseret på engagement $\mathrm{i}$ livschancer. Dette blev også præsenteret som en positivsumsløsning, da den "stresses a social policy more explicitly designed to optimize the self-reliant capacities of the citizenry. Again the core of such a model's social citizenship guarantees would combine education and proactive income maintenance" (1996: 264).

Kort sagt lægger social investeringsstrategi vægt på politikker, der er designet til at takle den påståede afvejning mellem effektivitet og lighed. Sociale investeringspolitikker fremmer typisk offentlig børnepasning og -uddannelse, human resource management og opkvalificering gennem livslang læring, nedbryder beskæftigelsesbarrierer (især for kvinder), afstemmer arbejde og omsorg (for børn), forebygger udtømning af human kapital, styrker arbejdsincitament og jobskabelse og fremmer arbejdsmarkedsfleksibilitet, mens det samtidig sikrer social beskyttelse (flexicurity) (Morel et al., 2009). Det overordnede mål for den fremspirende sociale investeringsstat er ifølge Jenson (2009: 27):

to increase social inclusion and minimise the intergenerational transfer of poverty as well as to ensure that the population is well prepared for the likely employment conditions (demand for higher educational qualifications; less job security; more precarious forms of employment) of contemporary economies. Doing so will allow individuals and families to maintain responsibility for their well-being via market incomes and intra-family exchanges, as well as lessening the threats to social protection regimes coming from ageing societies and high dependency ratios. The state's role is to define its interventions and social citizenship practices so that these conditions will be met. In policy terms 
this implies increased attention to and investment in children, human capital and making work pay.

Selvom den tredje vej blev en politisk fiasko, i hvert fald for europæiske socialdemokratiske partier (se Arndt, 2011), står dens nøgleoverbevisning stadig som et markant policy-paradigme, som nu også støttes - om ikke helhjertet, så i det mindste i policy-diskurser - af centrum-højreregeringer.

Ideen om social investering og behovet for at dyrke human kapital har været en del af det sociale policy-paradigme på europæisk niveau siden EU's Lissabon-topmøde i 2000. Lissabon-strategiens målsætninger er ganske vist ikke blevet opfyldt. Men overbevisningen om, at den sociale investeringsstrategi er den bedste vej mod justering af velfærdsstaten, og forventningen om, at det i det længere løb vil give økonomiske og sociale resultater, er stadig - mere eller mindre og på trods af den finansielle og økonomiske krise - intakte.

Det er vigtigt at slå fast, at tilslutning til det sociale investeringsparadigme ikke betyder, at nedskæringer er forsvundet fra den politiske dagsorden. Tværtimod medfører omstrukturering af sociale udgifter baseret på en social investeringslogik ofte nedskæringer i traditionelt passive ordninger. Desuden holder kravet om balance i budgettet under en finansiel krise den politiske opmærksomhed stramt fokuseret på nedskæringer. Endelig er det nye policyparadigme og den resulterende nedskæring på visse sociale policy-områder givetvis sket på bekostning af mere traditionelle indkomstbeskyttende policies med negative effekter for fattigdomsbekæmpelse og indkomstlighed; dog mere i nogle velfærdsstater ( $f x$ Storbritannien, Italien og Spanien) end i andre (nordvestlige Europa) (se Cantillon, 2011).

Med disse forbehold in mente hævder denne artikel, at de europæiske velfærdsstater har fulgt en social investeringslogik i deres reformagendaer. Denne approach er gearet til at sikre maksimalt udbytte på sociale udgifter i form af aktiv beskæftigelse og social deltagelse, specielt på arbejdsmarkedet, samt social sammenhængskraft og stabilitet. Man forventer, at velfærdsstaten hjælper arbejdsløse tilbage i beskæftigelse, at den supplerer arbejdsindkomsten for arbejdende fattige, at den sætter forældre i stand til at forene karriere og familieliv, at den fremmer lighed mellem kønnene, at den støtter børns udvikling, og at den leverer sociale ydelser til et ald rende samfund (Jenson, 2006). Vi vil her spore den sociale investeringsstrategis oprindelse og udvikling i store træk, beskrive dens hovedtræk og variationer og vise, hvordan og i hvilket omfang den har inspireret en betydningsfuld transformation af sociale policies og bidraget til en ny velfærdsstatsbygning. 


\section{Et fugleperspektiv på velfærdsstatsreform og nyskabelse}

Hvis vi definerer velfærdsstaten bredere end social beskyttelse, kan vi observere policy-ændringer på tværs af flere tæt forbundne policy-områder i de sidste tre årtier (se Hemerijck, 2012). Ændringerne er tydelige, dog med store variationer, i alle europæiske velfærdsstater uanset regimetype.

Makroøkonomisk politik var indtil sidst i 1970'erne domineret af keynesiansk makroøkonomisk politik med fuld beskæftigelse som det overordnede mål. Med 1970'erne fulgte stagflationen, altså en kombination af høj inflation og stigende arbejdsløshed. Det betød, at den keynesianske orden blev afløst af en strengere makroøkonomisk policy baseret på økonomisk stabilitet, hård valuta, lav inflation, solide budgetter, nedbringelse af gæld og monetær union. Med indførelsen af den fælles valuta blev monetær policy et permanent parameter for policy-reform på andre områder, undtaget $\mathrm{fx}$ indblanding i valutakurser og tvinge deltagende regeringer til at søge muligheder for velfærdsstatsjustering andre steder.

Den finansielle krise har dog motiveret regeringer til at foretage massive indgreb for - på bekostning af solide budgetter - at redde banksystemet og forhindre økonomien i at blive fanget i en nedadgående spiral. Grundlaget er keynesiansk inspirerede løsningsmodeller, der skal kompensere for effekten af de sandsynlige efterskælv (stigende arbejdsløshed, faldende værdi af pensionsmidler) og en tilbagevenden til den strenge makroøkonomiske tilgang, hvor nedskæringer fremhæves som en forudsætning for at balancere de offentlige budgetter (Starke, 2008; Hemericjk et al., 2009; Vis og van Kersbergen, 2011).

Inden for lønpolitik fandt der et sporskifte sted fra 1980'erne og frem til fordel for markedsbaseret løntilbageholdenhed i en situation med intensiveret økonomisk internationalisering. I fx Holland, Irland og Danmark var genopdagelsen af en beskæftigelsestung vækststi baseret på sociale pagter. I 1990'erne spillede EMU's adgangskrav ligeledes en afgørende rolle i genkomsten af nationale sociale pagter i Italien, Portugal og Grækenland, som kom med i den hårde valuta sent (Fajertag og Pochet, 2000; Ferrera og Gualmini, 2000). Den finansielle krise sætter dog sådanne sociale pagter under pres, fordi behovet for finanspolitisk konsolidering enten fører til smertefulde nedskæringer i velfærdsstaten eller til stigende skatter og bidrag og derfor til stigende efterspørgsel efter en form for kompensation.

Inden for arbejdsmarkedspolitik blev det ny mål at maksimere beskæftigelse i stedet for at tilskynde til exit fra arbejdsmarkedet. Dette betød nye forbindelser mellem beskæftigelsespolitik og social sikkerhed. Den nye approach fremhæver en kombination af investering i human kapital og stærkere incitamenter til at arbejde (Bonoli, 2009: 56-57). I alle lande (undtaget Italien) ser vi en 
stigning i aktive arbejdsmarkedspolitikker; nogle lande lægger dog også vægt på investering i human kapital (de nordiske lande og Frankrig), mens andre lande lægger vægt på at gøre det nemmere at komme tilbage på arbejdsmarkedet (Holland, Tyskland, Storbritannien). Der er dog også sammenfald, idet de fleste lande fokuserer på enten uddannelse eller fjernelse af barrierer for deltagelse i forbindelse med stærke arbejdsincitamenter. Bonoli (2009: 64) forventer, at den nuværende økonomiske krise med lange perioder med arbejdsløshed vil gøre arbejdsincitamenterne virkningsløse, hvilket forstærker behovet for og nytten (undgå udtømning af human kapital; opkvalificering) af human kapital-policies og jobskabelse.

Hvad angår arbejdsmarkedsregulering, antyder empiriske resultater fra Danmark og Holland, at flexicurity-systemer, som er baseret på minimal jobbeskyttelse og betydelig social beskyttelse af arbejdsløse, er bedst i stand til at slå bro over kløften mellem insidere og outsidere. Samtidig er det dog tvivlsomt, om flexicurity-modellen nyder tilstrækkelig støtte i samfundet (specielt blandt menige fagforeningsfolk) til at garantere dens fortsættelse i en kontekst af stigende budgetunderskud og fortsatte problemer i den finansielle sektor (Gazier, 2008, 2009). Især i Danmark er flexicurity-modellen kommet under pres på grund af de relativt lave vækstrater, den kumulerende negative vækst i 2008/2009 på 6,3 pct. og en støt stigende arbejdsløshed. Desuden har den finansielle krise og dens økonomiske følger gjort strengere jobbeskyttelse og statsstøttet intern fleksibilitet mere populære (Auer, 2010).

Inden for social forsikring er der sket et skifte fra passive policies for indkomstvedligeholdelse over mod større fokus på reintegration. Samtidig har politikere i mange lande valgt at styrke velfærdsstatens funktion som beskytter af minimumsindkomsten, sammen med stærke aktiverings- og reintegrationsinitiativer for at sikre en minimumsstandard for selvhjulpenhed. Men også tilbagerulning har stået højt på den politiske dagsorden og er flyttet opad på prioriteringslisten, nu da regeringer igen er begyndt at forsøge at få balance i budgetterne. Der har været nedskæringer i ydelsernes niveau og længde, stramninger af kriterierne for at modtage sociale ydelser og indskrænkning af ydelsernes dækningsgrad (Starke, 2008; Vis, 2010: 54), selvom omfanget af nedskæringer ikke skal overdrives (OECD, 2010).

Unges sene indtræden på arbejdsmarkedet, ældre arbejdstageres tidlige exit, kombineret med højere forventet livstid og lav fertilitet stiller mange velfærdssystemer over for et faretruende pensionsfinansieringsunderskud. Inden for alderspension står nedskæringer højt på dagsordenen. Men nedskæringer er bare ét aspekt af en mere omfattende omstrukturering og tilpasning til demografiske, økonomiske og sociale strukturelle ændringer (Häusermann, 2010). Nogle 
vigtige trends vedrører blandet andet væksten i (tvungne) arbejdsmarkeds- og private pensioner og udviklingen af flersøjlesystemer, der kombinerer pay as you go og fuldt finansierede metoder med relativt stramme (aktuarmæssige) links mellem pensionsydelser og -bidrag (Clark og Whiteside, 2003; Immergut et al., 2007).

Sociale ydelser: udgifter til børnepasning, uddannelse, sundhed og ældrepleje ved siden af videreuddannelse og beskæftigelse er steget i stort set hele EU i løbet af det sidste årti. Orlovsordninger bliver udvidet både tids- og dækningsmæssigt, til også at inkludere pasning af svage ældre. Desuden er kvinders beskæftigelse nøglen til bekæmpelse af børnefattigdom, som er stigende i de fleste europæiske lande. Det sociale investeringsperspektiv hævder her, at velfærdsstatens fremtid afhænger af, hvor godt dilemmaerne forbundet med kvinders nye karrierepræferencer bliver løst (Esping-Andersen, 2009). Kun en effektiv afstemning af familiefunktioner kan forventes at bidrage til en positivsumsløsning på afvejningen mellem kvinders beskæftigelse og fertilitet (Hakim, 2003; Orloff, 2006).

Hvad angår velfærdsstatens finansielle arkitektur, ser vi en stigning i brugerfinansiering inden for børnepasning, ældrepleje og lægehjælp. Med hensyn til beskatning har skærpet konkurrence i EU fået mange medlemslande til at anvende en kombineret strategi af lavere lovbestemt skattesats og bredere skattegrundlag. Behovet for at balancere budgettet i kølvandet på den finansielle krise har givet skatteproblemer en højere prioritet, ikke mindst i skatteineffektive lande som Grækenland.

Hvad angår makroøkonomiske resultater, er der en bemærkelsesværdig konvergens mellem prisstabilitet og finanspolitisk konsolidering. Der er en lignende tværnational konvergens i enhedslønomkostninger. Udgiftsniveauer på social beskyttelse i procent af bruttonationalproduktet (BNP) har holdt sig relativt stabile. Beskæftigelsesniveauer er konvergeret, og stort set alle velfærdsregimer har beskæftigelsesfrekvenser på mellem 65 og 75 pct. Den konvergerende trend er endnu stærkere for voksne arbejdstagere i "den bedste alder" (25-54 år), men aktivitetsniveauet er også steget blandt ældre arbejdstagere. I de yngre årgange er kvinders beskæftigelse i Syd- og Kontinentaleuropa steget. Dog er der dårligere muligheder for lavt kvalificerede på arbejdsmarkedet.

\section{Nationale og regimespecifikke faktorer}

På baggrund af disse generelle trends er det vigtigt at fremhæve væsentlige og vedvarende nationale forskelle og baner. Selvom vi tror, at den nye sociale investeringsstrategis fremkost i Europa givetvis udfordrer den veletablerede klassifikation af velfærdsstater i tre (eller fire) forskellige regimer, anerkender vi 
samtidig, hvor meget velfærdsstaternes set-ups stadig bestemmer muligheder og begrænsninger i socialpolitiske reformer. Derfor mener vi, at det er vigtigt og interessant at undersøge, om og i hvilket omfang nye sociale investeringspolicies varierer med forskellige regimelogikker.

Lad os først kort beskrive de forskellige velfærdsregimer. De nordiske velfærdsstater tilbyder generøse indkomstgarantier, en bred vifte af offentlige sociale ydelser og aktiv arbejdsmarkedspolitikker, der sigter efter at maksimere beskæftigelsen for både mænd og kvinder. Vi bruger Danmark som eksempel. Liberale velfærdsstater tilbyder relativt beskedne indkomstafhængige ydelser i tilfælde af arbejdsløshed, sygdom og alderdom, og der er strenge regler for socialhjælp. Her ser vi især på Storbritannien. De kontinentale velfærdsstater tilbyder relativt høje indkomsterstattende ydelser, der er linket til modtagerens beskæftigelseshistorie og familiesituation. Vi bruger Tyskland som eksempel, men ser også på Holland som hybrid og vigtig reform case.

\section{Nordisk "dobbelt indkomst" postindustrialisme og casen Danmark}

Det mest påfaldende træk ved det nordiske regime er kombinationen af generøse indkomstbevarende ydelser, veludviklede offentlige sociale ydelser og aktiv arbejdsmarkedspolitik, som understøtter høj erhvervsfrekvens for både mænd og kvinder. Sociale ydelser skaber ikke bare omfattende og ofte fleksible beskæftigelsesmuligheder i den offentlige sektor, men også ordentlige job til folk med beskedne kvalifikationer. Offentlig finansieret højere uddannelse og erhvervsuddannelse skaber innovation og øget produktivitet i faglærte stillinger i den private sektor. Prisen er, selvfølgelig, et meget højt skatteniveau. Derudover er den nordiske model under konstant pres for at holde budgetterne i balance, specielt efter den europæiske monetære integration.

De nordiske regimer præsterer bemærkelsesværdigt godt på trods af alle problemerne og den politiske kritik. Ikke bare er de nordiske lande kommet på fode igen efter monetære og økonomiske kriser, de har også genetableret balancerede budgetter og økonomisk dynamik, mens de har opretholdt et højt beskæftigelsesniveau og lave fattigdomsrater (cf. Ryner, 2007: 66). En væsentlig grund er, at de nordiske velfærdsstater allerede var forberedte på de "nye sociale risici" i det postindustrielle samfund (Bonoli, 2007), der socialiserede risici forbundet med aldrende samfund, ændrede samlivsformer og overgangen til videnøkonomien. Den sociale investeringsstrategi træder tydeligt frem, efterhånden som det nordiske regime fjerner sig endnu mere fra passiv understøttelse af arbejdsløse over mod aktiv promovering af beskæftigelse. 
Garanteret basisindkomst er et værn mod ikke bare fattigdom og udelukkelse men også mod den straf, der følger med arbejdsløshedsperioder og brudte eller sammensatte karrierer. Den brede vifte af ydelser betyder, at de nordiske velfærdsstater kan reagere effektivt på familiers pasningsbehov og socialisere deres omkostninger, inklusive omkostninger til børn. Den høje erhvervsfrekvens letter også det finansielle pres på pensionssystemerne. Endelig investerer de nordiske lande kraftigt i arbejdsmarkedsuddannelser, og de har de højeste uddannelsesudgifter som andel af BNP i Europa.

Danskerne er gået længst med den sociale investeringsstrategi, især i forhold til aktivering. En række arbejdsmarkedsreformer i 1990'erne indførte gradvist ret og pligt til aktivering. Dette omfattede introduktion af obligatoriske, individuelle handlingsplaner, som aktiverer den arbejdsløse inden for tre til fem måneder, samt afskaffelse af et system, der passivt udbetalte generøse ydelser (Albrechtsen, 2004: 224). Repertoiret af aktive arbejdsmarkedspolitikker blev derefter udvidet. Ud over tiltag på udbudssiden blev diverse orlovsordninger midlertidigt brugt til kunstigt at reducere efterspørgslen på arbejde i 1990'erne. Det var indførelsen af disse "aktive" elementer på det danske arbejdsmarked, der var grundlaget for flexicurity-modellen. Modellen triangulerer "flexible labour markets, generous unemployment benefits, and active labour market policies - all coordinated to reduce unemployment and improve the quality and supply of workers to the labour market" (Campbell og Hall, 2006: 30; se også Madsen, 2006). I løbet af 1990'erne blev ydelser til børn og unge samt mulighederne for forældreorlov udvidet, og aktiveringsinstrumenter rettet specielt mod mødre, der kom tilbage på arbejdsmarkedet, blev indført. Disse policies havde som mål at forbedre kvinders jobmuligheder og blev koblet til skabelsen af 50.000 job i den offentlige sektor mellem 1995 og 2001 (Dingeldey, 2005). Samtidig med at aktiveringstiltagene blev indført, blev kriterierne for at modtage kontanthjælp strammet. Den vigtigste ændring var, at kontanthjælpsperioden gradvist blev reduceret, men størrelsen af ydelsen faldt generelt ikke. Derudover blev den såkaldte "passivperiode" uden ret og pligt til aktivering sat ned for voksne jobsøgere i 2007 (Kvist et al., 2008: 227). Danmark indtog således en "arbejde først"-holdning med fokus på kontrol af ydelser, rådighedstests og jobvejledning.

\section{Den liberale "tredje vej" og den britiske case}

Storbritannien har udstukket en ny kurs, der stort set følger det sociale investeringsparadigme, men med klare liberale træk. Aktiveringspolicies er dog blevet kraftigt udvidet for at hjælpe markedsøkonomien og mindske fattigdomsrisici. Aktiveringspolitikken bevæger sig væk fra passive, behovsbestemte ordninger 
over mod i arbejde-fordele. Siden 1997 har skiftende regeringer forladt den strengt liberale sti og udviklet en liberal version af social investering, den såkaldte "aktiverende" velfærdsstat, hvor lønnet beskæftigelse er en betingelse for de fleste ydelser (Clasen, 2005). Det mest fremtrædende eksempel er introduceringen af the New Deal i 1998, som var baseret på et krav om, at arbejdsløse aktivt skal søge arbejde for at få ydelser (Weishaupt, 2010).

Regeringen stræbte efter at tilbyde uddannelse eller jobs til 250.000 unge og brugte mere end $£ 3$ milliarder på unge alene (http://archive.treasury.gov.uk/ pub/html/budget97/hmt2.html). The New Deal for Young People har således været langt det største New Deal-program. Det tilbyder arbejdsløse fire muligheder: tilskudsjob i den private sektor; midlertidigt job med tilskud i frivillig- eller miljøsektoren; fuldtids uddannelse; eller jobtræning. Der er dog ingen "femte mulighed" for at leve på passive ydelser, og tilsidesættelse af reglerne kan føre til tab af ydelser og i sidste ende suspension. Ordningen er blevet udvidet til at omfatte arbejdsløse voksne og andre målgrupper som enlige forældre, kronisk handicappede og ældre arbejdere.

For at begrænse visse byrder blev supplerende policies introduceret, $\mathrm{fx}$ national mindsteløn. En anden søjle i "arbejde skal kunne betale sig"-strategien vedrører den relativt generøse Working Families Tax Credit, som belønner dem, der er i arbejde, med tæt på et tidobbelt skattefradrag (Nachtwey og Heise, 2006: 6). Det er efterfølgende blevet udvidet til voksne uden børn og dækker også delvist udgifter til børnepasning, hvis det er relevant. Alt i alt betyder skattefradragene og mindstelønnen, at alle, der arbejder mindst 30 timer om ugen, har modtaget en indkomst, der ligger over fattigdomsgrænsen (Brücker og Konle-Seidl, 2006: 5). Derudover er forskellig lovgivning blevet sat i gang, der skal gøre det nemmere at kombinere familie og arbejde (flere børnepasningspladser, betalt barsel, ret til orlov for fædre og mere fleksible arbejdstider (Clasen, 2005).

At takle Storbritanniens underskud af faglige kvalifikationer blev også en del af den sociale investeringsdagsorden. En væsentlig del af Storbritanniens kvalifikationsstrategi har været indførelsen af instrumenter til opkvalificering af lavt uddannede arbejdere. Fx tilbyder en ordning, der kaldes "The Train to Gain", lavt uddannede arbejdere fuldt betalt adgang til jobtræning og arbejdsgivere tilskud som kompensation for tabt arbejdstid (Page og Hillage, 2006). I 2006 indførte man en lovfæstet ret for voksne til at opnå et vist niveau af kvalifikationer uden undervisningsgebyr (Weishaupt, 2010). 


\section{At vende det kontinentale "velfærd uden arbejde"-syndrom og den tyske og hollandske case}

Den kontinentale velfærdsstat er blevet beskrevet som et "velfærd uden arbejde"-system (Esping-Andersen, 1996). Historisk har dominansen af kristen "familialisme" opfordret kvinder til at blive hjemme i stedet for at deltage på arbejdsmarkedet og tilskyndet til en høj familieløn til mandlige forsørgere (van Kersbergen, 1995). På den anden side reducerede høje lønninger jobskabelse, især inden for services der kræver lav uddannelse og har lav produktivitet.

Som en forværrende omstændighed blev den industrielle omstrukturering i 1970'erne og 1980'erne hjulpet på vej af en stor udvidelse af efterlønsordninger, hvilket katalyserede de afskedigelsestendenser, der allerede var forbundet med globalisering og afindustrialisering. Den resulterende selvforstærkende negative spiral har allerede haft store konsekvenser for lavt kvalificerede arbejdere, unge og kvinder. Budgetmæssigt pres for at skære ned på populære og generøse indkomsterstattende ordninger står i skarp kontrast til nye krav om social beskyttelse, der opstår pga. traditionelle familiestrukturers forfald og manglende udvidelse af offentlige og private servicesektorer.

Det kontinentale syndrom har genereret en kompleks reformdagsorden: begrænse sociale udgifter ved at trimme "passive" ydelser, indførelse af "aktive" incitamenter i andre kontantydelser, udvidet børnepasning og forældreorlov, øgning af trangsbestemte ydelser og nedsættelse af lønningsafgifter. Imidlertid har de kontinentale velfærdsstater, fordi de har været så langt fra ideen om social investering, måske foretaget de mest dramatiske og banebrydende reformer i deres accept af det sociale investeringsparadigme.

At øge erhvervsfrekvensen blandt kvinder, lavt uddannede grupper og ældre arbejdere blev set som absolut nødvendigt for at sikre velfærdsstatens overlevelse i det lange løb. Følgelig har de fleste kontinentale velfærdsstater øget udgifterne til aktiv arbejdsmarkedspolitik. Større pres på de arbejdsløse for at acceptere passende jobtilbud eller deltage i jobtræning har styrket aktiveringsprogrammer. Siden først i 1990'erne har man gjort en indsats for at reducere tidlig exit ved at stramme kriterier, sænke ydelser, indføre strengere kontrol, og i de tidlige 00'ere blev efterlønsordninger helt afskaffet.

De sidste to årtier har også kontinentet fået øjnene op for aktiveringsprogrammer baseret på individuel vejledning og jobtræningsmuligheder, der primært er målrettet "outsidere" som unge, kvindelige eller lavt kvalificerede arbejdere. Disse reformer er begyndt at flytte privilegier væk fra insidere (mandlige forsørgere og deres pårørende) ved at give outsidere adgang til forsikringsydelser, indføre betalt barselsorlov og forbedre deltidsansattes sociale rettigheder og minimums indkomstbeskyttelse. 
Samtidig siger de kontinentale velfærdsstater farvel til det traditionelle familie-ideal og vælger reformer, der giver kvinder mulighed for at deltage på arbejdsmarkedet. Forældreorlovsordninger blev udvidet, og pasning af svagelige ældre og syge børn indført. Især siden slutningen af 1990'erne er børnepasning blevet udvidet (Morgan, 2009: 47). Regeringerne har øget forbruget og presset på for mere fleksible åbningstider i børnepasningsinstitutioner for at øge antallet af ledige og billige pladser, dog uden at indikere commitment til en "servicestat" (Morgan, 2009: 52).

Indtil midt-1990'erne, var den tyske velfærdsstat berygtet for sin modvilje mod radikal reform (Bönker og Wollmann, 2001; Obinger og Starke, 2007; Stiller, 2010), men den har faktisk taget en dramatisk drejning mod aktivering. I 2001 øgede Job-AQTIV loven fx offentlig beskæftigelse og åbnede op for bred og tidlig adgang til jobtræningsprogrammer. I 2004 og 2005 udvidede de vigtige Hartz-reformer lavtlønssektoren via nye skatte- og afdragsfritagelser og nedsættelser. De mest kontroversielle elementer vedrørte ændringerne i arbejdsløshedspolitik, hvilket involverede drastisk forkortet varighed af ydelser for alle arbejdsløse, hævning af førtidspensionsalderen for ældre arbejdsløse fra 60 til 63, skærpede krav om at acceptere passende job, forenklede forsikringsregler og sammenlægning af arbejdsløshedsstøtte og socialhjælp (Weishaupt, 2010).

En anden type reformer taklede postindustrielle sociale risici forbundet med kvindernes massive indtog i lønnet beskæftigelse. Som en hjælp til at få familie og arbejde til at balancere, blev børnepasning og forældreorlovsordninger udvidet. Orlovsordninger blev udvidet til at omfatte deltidsansatte, to måneders fædreorlov til arbejdende fædre og en firedobling af maksimumydelsen fra sidst i 1990'erne. Derudover er heldagspasning for børn under tre blevet udvidet (Korthouwer, 2008; Morgan, 2009).

Den hollandske velfærdsreform fandt sted tidligere end den tyske og var baseret på en langsigtet strategi for organiseret løntilbageholdenhed, begrænsning af adgang til (og bremsning af stærkt misbrug af) invalidepensioner og sygdomsforsikring, og promovering af deltidsarbejde (Visser og Hemerijck, 1997). I 1995 fandt de sociale parter en perfekt balance mellem fleksibel beskæftigelse opnået ved at beskytte social sikring og deltids- og midlertidigt ansattes retsstilling mod at lempe en smule på lovgivningen om afskedigelse af ansatte (flexicurity). Arbejdstidsloven fra 2000 giver nu udtrykkeligt deltidsansatte ret til lige behandling på alle områder, der forhandles af de sociale parter (Hemerijck, 2003; Vis et al., 2008).

Mellem 2003 og 2006 forsøgte Holland at øge erhvervsfrekvensen og politikerne valgte i den forbindelse både pisk og gulerod. Siden 2004 skal ældre 
arbejdsløse søge job, og arbejdsgivere er ikke længere forpligtet til at betale bonusser til uarbejdsdygtige ansatte over 55. I 2005 nedsatte regeringen ydelserne til delvist uarbejdsdygtige personer, som ikke er i arbejde, men udvidede også mulighederne for jobtræning og oprettede løntilskud til delvist uarbejdsdygtige og deres arbejdsgivere. Skattefordele ved førpensionsordninger blev erstattet af en livsforløbsordning, der stimulerer arbejdstagere til at opspare 210 pct. af deres årsløn ved at opspare et årligt maksimum på 12 pct. af deres årsindkomst. Arbejdstagere kan således modtage 70 pct. af deres årlige løn, mens de er på orlov (forældreorlov, uddannelsesorlov, sabbatår eller efterløn) i tre år. For at skabe endnu bedre balance mellem arbejds- og familieliv modtager de, der anvender livsforløbsordningen, når de er på forældreorlov, en ekstra udbetaling, der svarer til 50 pct. af mindstelønnen. Derudover har man oprettet og givet tilskud til ekstra børnepasningsfaciliteter på skoler, men Holland halter stadig bagefter på børnepasningsområdet.

Alt i alt har de kontinentale velfærdsstater ændret sig betydeligt mere end deres nordiske og liberale modstykker. Deres accept af ideen om social investering krævede justering af to kerneværdier i den kontinentale velfærdsstat: statusbevarelse og støtte til den traditionelle familie. De blev erstattet af promovering af lige muligheder via deltagelse på arbejdsmarkedet og fattigdomsbekæmpelse. Vi observerer en udvikling hen imod en aktiverende velfærdsstat, der forstærker de sociale rettigheder og kvinders og især lavt kvalificerede gruppers jobparathed.

\section{Konklusion}

Overalt i Europa har den sociale investeringsstrategi på mange måder informeret reformen af velfærdsstaten. Selvom mange af justeringerne i stort omfang har været regimespecifikke, har der også været temmelig radikale, banebrydende reformer hen imod den aktiverende velfærdsstat, specielt i gruppen af kontinentale velfærdsstater. I denne henseende konvergerer de europæiske velfærdsstater. Denne udvikling betyder især, at tiden er moden til et kritisk tjek af den eksisterende regimetypologi, men det er dog ikke noget, vi vil tage op i denne artikel. Indtil videre vil vi bare konkludere, at ideen om social investering har etableret sig selv som grundlag for et nyt policyparadigme på tværs af regimerne.

Hvis vi ser på beskæftigelsesmønstre og -baner, træder aktiveringssiden af den nye sociale investeringslogik klart frem. I nogle tilfælde, fx afskedigelsespolitik i forbindelse med efterløn, er målet helt tydeligt at vende udviklingen. I andre tilfælde følger den sikkert udviklingen, men forstærker og fremskynder den fx med hensyn til kvinders beskæftigelsesmønstre. Som vi antydede, er 
tilbagerulning af socialpolitik helt sikkert også en del af historien, men heller ikke mere: en del af historien om to årtiers socialpolitisk forandring. Den anden del af historien er den overraskende vidtrækkende og vellykkede accept af den sociale investeringsdagsorden i de fleste, om ikke alle velfærdsstater, uanset regimetype.

Der er to spørgsmål, vi gerne vil tage op i konklusionen: (1) Gør den finansielle krise og dens økonomiske efterdønninger det mere sandsynligt, at centrum-højreregeringer, som måske nok aldrig har taget den sociale investeringsdagsorden 100 pct. til sig, vil vende tilbage til en langt strengere dagsorden for tilbagerulning af velfærdsstaten, men måske blive ved med at tale paradigmets jargon? Et eksempel kunne være den britiske centrum-højreregering (konservative og liberale), som i sit 2011-budget planlagde en uhørt tilbagerulning på $£ 126$ milliarder (ca. € 144 milliarder, 8,7 pct. af BNP) om året før 2015-2016. Dette beløb skal opnås gennem totale nedskæringer i forbrug på $£ 95$ milliarder (ca. $€ 108$ milliarder, 6,6 pct. af BNP) og en nettostigning i skatter på $£ 30$ milliarder (€ 34 milliarder, 2,1 pct. af BNP) (UK HM Treasury, 2011: 10).

(2) Har accepten af det sociale investeringsparadigme ført til negligering af sociale politikker designet til sociale risici, der er svære at dække med aktiveringspolitikker? Kan der være sket en afvejning mellem sociale investeringsstrategier, der stimulerer jobvækst, og omfordelingspolitikker, der dæmper uligheden (Cantillon, 2011)? Vi har været vidne til en kovending i udviklingen i uligheden: Den faldt i efterkrigstiden indtil omkring sidst i 1970'erne, men steg så pludseligt. Uligheden er steget lige siden, mens fattigdomsrisikoen næsten ikke eller måske slet ikke er faldet (OECD, 2008). Det afgørende spørgsmål er, om stigende ulighed er et direkte resultat af transformationen af velfærdsstaten ifølge den sociale investeringslogik. Dens fokus på udbudspolitik, aktivering og beskæftigelse, kort sagt på arbejdsmarkedets funktion, giver en risiko for, at lønforskellene stiger. Desuden må den sociale investeringslogik regnes som medansvarlig for øget ulighed, hvis den nedsætter den omfordelende effekt af skatter og ydelser (Brandolini og Smeeding, 2009). Men siden uligheden allerede var begyndt at vokse, lang tid før de sociale investeringsstrategier blev introduceret, er spørgsmålet om deres effekt mere kompliceret. Ud over at det tager lang tid, før man ser udbyttet af sociale investeringer, påvirker andre faktorer også fordelingen af indkomster. Globalisering og teknologi øger fx efterspørgslen efter (højt) uddannet arbejdskraft og øger lønuligheden mellem faglærte og ufaglærte arbejdstagere, og sociale investeringspolicies (fx uddannelse, jobtræning) er designet til at modvirke sådanne effekter.

Vi kan ikke tage diskussionen længere, men der er helt klart brug for mere forskning på området. Vi kan dog konkludere, at aktivering og fremkomsten 
af den sociale investeringsstat har haft relativ stor succes med at stimulere deltagelse på arbejdsmarkedet, men også at social ulighed er steget, at risikoen for fattigdom ikke er faldet, og at paradigmets skæbne i krisetider er usikker. Fleksible arbejdsmarkeder har en tendens til at øge lønforskelle, og aktiveringspolitik er designet til de arbejdsduelige eller til at øge arbejdsdueligheden. Med andre ord fokuserer logikken i social investering på at maksimere chancerne for at tjene en indkomst på arbejdsmarkedet, og markedet har en tendens til at generere uligheder og risici. Nødvendigheden af at balancere budgettet og ustabil politisk tilslutning til det sociale investeringsparadigme gør dens umiddelbare fremtid usikker. Men hvis den sociale investeringsstrategi fortsat får politisk opbakning og forbliver koblet med mindsteløn, uddannelse, jobtræning og opkvalificering, kan man godt forestille sig forøgede lige muligheder og endda faldende indkomstulighed.

\section{Note}

1. Som konsulent har Esping-Andersen aktivt promoveret social investeringspolitik over for regeringer ( $\mathrm{f}_{\mathrm{x}}$ Holland, Tyskland, Catalonien), diverse relevante organisationer, inklusive FN, OECD, Vatikanet (!) og forskellige EU-formandskaber. Han har været medlem af EU-kommissionsformand Barrosos socialpolitiske ekspertpanel.

\section{Litteratur}

Albrechtsen, Helge (2004). Active Young People in Europe: Denmark, Germany and the UK, i Amparo Serano Pascual (red.), Are Activation Policies Converging in Europe? The European Employment Strategy for Young People. Brussels: ETUI.

Arndt, Christoph (2011). The Electoral Consequences of Third Way Welfare State Reforms. Social Democracy's Transformation and Its Political Costs. Ph.d.-afhandling, Institut for Statskundskab, Aarhus Universitet.

Auer, Peter (2010). What's in a Name? The Rise (and Fall?) of Flexicurity. Journal of Industrial Relations 52 (3): 371-386.

Bonoli, Giuliano (2007). Time Matters. Postindustrialization, New Social Risks, and Welfare State Adaptation in Advanced Industrial Democracies. Comparative Political Studies 40 (5): 495-520.

Bonoli, Giuliano (2009). Varieties of Social Investment in Labour Market Policy, i Nathalie Morel, Bruno Palier og Joakim Palme (red.), What Future for Social Investment? Stockholm: Institute for Future Studies.

Bönker, Frank og Hellmut Wollman (1996). Incrementalism and Reform Waves: the Case of Social Service Reform in the Federal Republic of Germany. Journal of European Public Policy 3 (3): 441-460. 
Brandolini, Andrea og Timothy M. Smeeding (2009). Income Inequality in Richer and OECD Countries, in Wiemer Salverda, Brian Nolan og Timorthy M. Smeeding (red.), The Oxford Handbook of Economic Inequality. Oxford: Oxford University Press.

Brücker, Herbert og Regina Konle-Seidl (2006). Kombilöhne im internationalen Vergleich: Nicht jede Therapie schlägt überall an. IAB-Kurzbericht, 10/2006. Nürnberg.

Campbell, John L. og John A. Hall (2006). Introduction: The State of Denmark, i John L. Campbell, John A. Hall og Ove Kaj Pedersen (red.), National Identity and the Varieties of Capitalism: The Danish Experience. Montreal: McGill University Press.

Cantillon, Bea (2011). The Paradox of the Social Investment State: Growth, Employment and Poverty in the Lisbon Era. Journal of European Social Policy 21 (5): 432449.

Clark, Gordon L. og Noel Whiteside (2003). Pension Security in the 21st Century. Oxford: Oxford University Press.

Clasen, Jochen (2005). Reforming European Welfare States. Germany and the United Kingdom Compared. Oxford: Oxford University Press.

Dingeldey, Irene (2005). Welfare State Transformation between Workfare and an Enabling State: A Comparative Analysis. No 21, TranState Working Papers, University of Bremen, Collaborative Research Center 597: Transformations of the State.

Esping-Andersen, Gøsta (1996). Welfare States in Transition. London: Sage.

Esping-Andersen, Gøsta (2009). The Incomplete Revolution. Adapting to Women's New Roles. Cambridge: Polity Press.

Fajertag, Giuseppe og Philippe Pochet (2000). Social Pacts in Europe: New Dynamics. Brussels: ETUI.

Ferrera, Maurizio og Elisabetta Gualmini (2000). Italy: Rescue from Without?, i Fritz W. Scharpf og Vivien A. Schmidt (red.), Welfare and Work in the Open Economy, vol. II, Diverse Responses to Common Challenges. Oxford: Oxford University Press.

Gazier, Bernard (2008). Flexicurité et Marchés Transitionnels du Travail : esquisse d'une réflexion normative. Travail et Emploi 113: 117-128.

Gazier, Bernard (2009). The European Employment Strategy in the Tempest: Restoring a Long-Term Perspective, i Natalie Morel, Bruno Palier og Joakim Palme (red.), What Future for Social Investment? Institute for Future Studies Research Report. Stockholm: Institute for Future Studies.

Hakim, Catherine (2003). Work-Lifestyle Choices in the Twenty-First Century. Oxford: Oxford University Press.

Häusermann, Silja (2010). The Politics of Welfare State Reform in Continental Europe: Modernization in Hard Times. Cambridge: Cambridge University Press. 
Hemerijck, Anton (2003). Vier kernvragen van beleid. Beleid en Maatschappij 30 (1): 3-19.

Hemerijck, Anton (2012). Changing Welfare States. Oxford: Oxford University Press. Hemerijck, Anton, Ben Knapen og Ellen van Doorne (2009). Aftershocks. Economic Crisis and Institutional Choice. Amsterdam: Amsterdam University Press.

Immergut, Ellen, Karen Anderson og Isabelle Schulze (red.) (2007). The Oxford Handbook of West European Pension Politics. Oxford: Oxford University Press.

Jenson, Jane (2006). The European Social Model: Gender and Generational Equality, i Anthony Giddens, Patrick Diamond og Roger Liddle (red.), Global Europe, Social Europe. Cambridge: Polity Press.

Jenson, Jane (2009). Redesigning Citizenship Regimes after Neoliberalism. Moving Towards Social Investment, i Nathalie Morel, Bruno Palier og Joakim Palme (red.), What Future for Social Investment? Stockholm: Institute for Future Studies.

Korthouwer, Gerben (2008). How German Christian Democrats Have Said Farewell to Famialism. ASSR Working Papers 08/01.

Kvist, Jon, Lisbeth Pedersen og Peter Köhler (2008). Making All Persons Work: Modern Active Labour Market Policies, in Werner Eichhorst, Otto Kaufmann og Regina Konle-Seidl (red.), Bringing the Jobless Into Work? : Experiences with Activation Schemes in Europe and the US. Berlin: Springer.

Madsen, Per K. (2006). How Can It Possibly Fly? The Paradox of a Dynamic Labour Market in a Scandinavian Welfare State, i John L. Campbell, John A. Hall og Ove Kaj Pedersen (red.), National Identity and Varieties of Capitalism: The Case of Denmark. Montreal: McGill University Press.

Morel, Nathalie, Bruno Palier og Joakim Palme (2009). What Future for Social Investment? Stockholm: Institute for Future Studies.

Morgan, Kimberly (2009). Child Care and the Social Investment Model: Political Conditions for Reform, i Nathalie Morel, Bruno Palier og Joakim Palme (red.), What Future for Social Investment? Stockholm: Institute for Future Studies.

Nachtwey, Oliver og Arne Heise (2006). Großbritannien: Vom kranken Mann Europas zum Wirtschaftswunderland? WSI-Mitteilungen 3: 131-137.

Obinger, Herbert og Peter Starke (2007). Sozialpolitische Entwicklungstrends in OECD-Ländern 1980-2001: Konvergenz, Divergenz oder Persistenz? Politische Vierteljahresschrift, special issue Transfer, Diffusion und Konvergenz von Politiken, by Katharina Holzinger/Helge Jörgens/Christoph Knill (red.), 470-495.

OECD (2008). Growing Unequal? Income Distribution and Poverty in OECD-Countries. Paris: OECD.

OECD (2010). Employment Outlook 2010. Moving beyond the Jobs Crisis, Paris: OECD. See http://www.oecd.org/document/22/0,3746,en_2649_33927_43221014_1_1_1 _1,00.html\#taxes. 
Orloff, Anne Shola (2006). Farewell to Maternalism, i Jonah D. Levy (red.), The State After Statism. New State Activities in the Age of Liberalization. Cambridge, MA: Harvard University Press.

Page, Rosie og Jim Hillage (2006). Vocational Education and Training in the UK. Discussion Paper, Wissenschaftszentrum Berlin fur Socialforschung.

Ryner, Magnus (2007). The Nordic Model: Does It Exist? Can It Survive? New Political Economy 12 (1): 61-70.

Starke, Peter (2008). Radical Welfare State Retrenchment: A Comparative Analysis. Houndmills, Basingstoke: Palgrave Macmillan

Stiller, Sabina (2010). Ideational Leadership in German Welfare State Reform. Amsterdam: Amsterdam University Press

UK HM Treasury (2011). 2011 HM Treasury Budget. http://cdn.hm-treasury.gov. uk/2011budget_complete.pdf (February 2012).

Van Kersbergen, Kees (1995). Social Capitalism. A Study of Christian Democracy and the Welfare State. London/New York: Routledge.

Vis, Barbara (2010). Politics of Risk-Taking: Welfare State Reform in Advanced Democracies. Amsterdam: Amsterdam University Press.

Vis, Barbara og Kees van Kersbergen (2011). To What Extent Did the Financial Crisis Intensify the Pressure to Reform the Welfare State? Social Policy \& Administration 45 (4): 338-353.

Vis, Barbara, Kees van Kersbergen og Uwe Becker (2008). The Politics of Welfare State Reform in the Netherlands: Explaining a Never-Ending Puzzle. Acta Politica 43 (2-3): 333-356.

Visser, Jelle og Anton Hemerijck (1997). A Dutch Miracle, Job Growth, Welfare Reform and Corporatism in the Netherlands. Amsterdam: Amsterdam University Press

Weishaupt, Timo (2010). From the Manpower Revolution to the Activation Paradigm. Explaining Institutional Continuity and Change in an Integrating Europe. Amsterdam: Amsterdam University Press. 